\title{
Bilateral Congenital Cataract: Deprivation Amblyopia and its relation to development
}

\section{Catarata congénita bilateral: ambliopía por deprivación y su relación con el desarrollo}

\author{
Lizbeth Uribe-Campos ${ }^{1,2 *}$, Leticia Arroyo-Muñoz ${ }^{3}$, Mario Mandujano-Valdés², Hortensia Moreno-Macias ${ }^{4}$, \\ Juan C. Zenteno-Ruíz ${ }^{5,6}$, Roxana Muñoz-Hernández ${ }^{7}$ and Carmen Sánchez ${ }^{2}$
}

${ }^{1}$ Doctorate in Biological and Health Sciences, Universidad Autónoma Metropolitana; ${ }^{2}$ Laboratory of Neurodevelopment Follow-up of the Instituto Nacional de Pediatría, Universidad Autónoma Metropolitana-Xochimilco; ${ }^{3}$ Fundación Hospital de Nuestra Señora de la Luz; ${ }^{4}$ Department of Economics, Universidad Autónoma Metropolitana-Iztapalapa; ${ }^{5}$ Department of Genetics-Research Unit, Instituto de Oftalmología Conde de Valenciana; ${ }^{6}$ Department of Biochemistry, Faculty of Medicine, Universidad Nacional Autónoma de México; ${ }^{7}$ Department of Economic Production, Universidad Autónoma Metropolitana-Xochimilco. Mexico

\begin{abstract}
Purpose: To determine the impact of age at the time of bilateral congenital cataract (BCC) surgery, regarding changes in cognitive, language and motor development, considering the results of visual function. Methods: This is an ambispective descriptive longitudinal study of the evolution of visual acuity and development, using Teller Acuity Cards, Retinoscopy, and the Bayley Scales of Infant and Toddler Development, Third edition. Eight patients with BCC were included to establish the general conditions of onset with longitudinal follow-up after surgery. Patients were divided into two groups, considering the age of treatment (early treatment $<6$ months; late treatment $>6$ months). We used non-parametric statistics with trend tests in the two groups, using a significance level of $p<0.05$. A description of visual development was made through a qualitative analysis. Results: Refractive errors decreased progressively, with a statistically significant difference between both groups ( $p$ $<0.01)$. The cognitive area showed improved outcomes with a significant difference $(p=0.012)$ in the early treatment group. Conclusions: Late surgical treatment led to severe disturbances in the organization of visual function, as well as in observable behaviors of the motor, cognitive, and language areas, limiting a comprehensive and adequate development of children. It is necessary to implement strategies that include visual rehabilitation and early intervention for developmental disturbances.
\end{abstract}

Key words: Congenital cataract. Visual deprivation. Amblyopia. Visual function. Development.

\section{Resumen}

Objetivo: Determinar el impacto de la edad de cirugía en la catarata congénita bilateral (CCB) sobre los cambios en el desarrollo cognitivo, motor y del lenguaje, considerando los resultados de la función visual. Método: Se trata de un estudio descriptivo, longitudinal y ambispectivo de la evolución de la agudeza visual y del desarrollo, que utilizó las cartillas de agudeza visual de Teller, retinoscopia y la Escala de Desarrollo Infantil Bayley III. Fueron incluidos ocho pacientes con CCB para establecer las condiciones generales de inicio, con un seguimiento longitudinal después de la cirugía. Los pācientes

Correspondence:

*Lizbeth Uribe-Campos

Alumnos, 53

Col. S. Miguel Chapultepec, Del. Miguel Hidalgo Date of reception: 11-07-2017

C.P. 11850, Ciudad de México, México Date of acceptance: 01-03-2018

E-mail: lizbethuribe_opt@ hotmail.com DOI: 10.24875/RMOE.M18000019 license (http://creativecommons.org/licenses/by-nc-nd/4.0/).

Available online: 16-07-2018

Rev Mex Oftalmol (Eng). 2018;92(4):163-173 www.rmo.com.mx er the CC BY-NC-ND 
fueron divididos en dos grupos según la edad de tratamiento (tratamiento temprano $<6$ meses y tratamiento tardío $>6$ meses). Se utilizó estadística no paramétrica mediante la prueba de tendencia a través de grupos ordenados utilizando un nivel de significancia de $p<0.05$. A través de un análisis cualitativo se realizó una descripción del desarrollo visual. Resultados: El error refractivo disminuyó de manera progresiva y mostró una diferencia estadísticamente significativa entre ambos grupos $(p<0.01)$. El área cognitiva mostró mejores resultados en el grupo de tratamiento temprano $(p=0.012)$. Conclusión: El retraso en el tratamiento quirúrgico conduce a graves alteraciones en la organización de la función visual, así como en los comportamientos observables en el área motora, cognitiva y del lenguaje, lo que limita el desarrollo integral y adecuado en el individuo. Es necesaria la implementación de estrategias que incluyan la rehabilitación visual y la intervención temprana de alteraciones del desarrollo.

Palabras clave: Catarata congénita. Deprivación visual. Ambliopía. Función visual. Desarrollo.

\section{Introduction}

Worldwide, it is estimated that the number of children with visual disabilities is 19 million, of which 12 million suffer from refractive errors that could be easily diagnosed and correctable ${ }^{1}$; more than $90 \%$ live in developing countries and more than two thirds could have been avoided ${ }^{2}$. It is estimated that 1.4 million children under 15 years of age suffer irreversible blindness and need visual rehabilitation for their full psychological and personal development ${ }^{1}$. The main causes of blindness in children vary from one region to another and are largely associated with socioeconomic development and the availability of health care services ${ }^{3}$. It is estimated that in almost half of blind children the underlying cause could have been avoided if there was a visual detection program ${ }^{3}$.

However, there are important causes that are indistinct in all countries, such as congenital cataracts (CC), congenital ocular anomalies and hereditary retinal dystrophies.

CC refers to an opacity of the lens acquired during prenatal development ${ }^{4}$. It represents $13 \%$ of the causes of visual decline in children and is considered the most frequent cause of treatable visual deprivation. It has a prevalence of 1 to 4 per 10,000 children in developed countries and of 5 to 15 in developing countries ${ }^{4-8}$, with a global report of 200,000 blind children due to $\mathrm{CC}^{2,3,5,9}$. It is the most important cause of blindness and is responsible for 5 to $20 \%$ of blindness in children worldwi$\mathrm{de}^{9}$. In a systematic review of the prevalence of CC in several countries, an average prevalence of 1.03 per 10,000 children was identified, with an average incidence of 1.8 to 3.6 per 10,000 children per year ${ }^{10}$. In Latin America, it is estimated that one out of every 300 births per year present CC, and is responsible for $20 \%$ of the causes of blindness in childhood ${ }^{11}$. In Mexico, a compilation of data from different ophthalmological hospitals in Mexico City and the Instituto Nacional de
Pediatría shows that in the last 10 years, 260 CC diagnoses were made before two years of age, from which only $18.46 \%$ underwent surgery ${ }^{12-15}$. In the Hospital General de México it is reported that bilateral CC (BCC) is more frequent $(65 \%)$ than unilateral $\mathrm{CC}(35 \%)$, and strabismus appears as the most frequent sequela after surgery $(25 \%)^{11}$. The main cause of CC is idiopathic, followed by the inherited one; however, it may be due to a metabolic alteration (galactosemia, hemolytic anemia and hypoglycemia), or even have an infectious origin when it occurs during the first trimester of pregnancy (TORCH syndrome). However, there is a large variety of chromosomal and dysmorphic syndromes with a high risk of developing cataract (trisomy 21 and Turner syndrome) $)^{4,16}$.

The management of CC will depend on the etiology, laterality, type of cataract and the degree of visual impairment ${ }^{5}$. The decision to perform surgery will depend on the clinical judgment of the ophthalmologist, who will take into account the presence of significant visual deprivation or if the cataract is visually significant, which will depend on its morphology, size, position and density ${ }^{4}$. In most cases, the diagnosis is usually late because there is no single universal model for the evaluation of visual development in children; however, there are tests that determine the integrity of visual function, such as the observation of the fixation pattern and visual monitoring ${ }^{17}$.

Deprivation amblyopia can be defined as an interruption in the development of visual acuity caused by a lack or inappropriate visual stimulation. Critical and sensitive periods have an important role in visual development ${ }^{18}$. Amblyopia caused by $\mathrm{CC}^{16}$ is due to anatomical and physiological structural abnormalities ${ }^{19}$ that are accompanied by visual loss ${ }^{20}$. Amblyopia's reversibility will depend on the maturation states of the visual system ${ }^{18}$, the restriction's duration and the age of treatment ${ }^{21}$. If amblyopia is present during the critical period of visual development, optical and oculomotor 
deficiencies will cause the loss of neural connections involved in the visual pathway that will affect binocular vision, which influences the control and manipulation of tasks that require three-dimensional vision. Mainly, it will affect visual-motor integration of tasks that require deep perception and fine motor skills that require handeye and foot-eye coordination ${ }^{22}$.

Detection and early treatment in patients with $\mathrm{CC}$ are important because child's development in the first two years of life is mainly linked to movement and perception. Cognitive schemes related to the construction of object permanence, the perception of space and gestural imitation could be delayed by visual difficulties when performing movements that limit the reach, manipulation and exploration of objects ${ }^{22}$.

Some studies have established that children with visual impairment have a delay in neuro psychomotor development due to a limited interaction with their environment and with objects that favor learning ${ }^{23}$. The development of sensory functions requires the experience obtained during early childhood, so a congenital abnormality can modify visual, auditory and tactile abilities, disturbing the interaction with the environment ${ }^{24,25}$. Therefore, the importance of the study lies in determining the impact of visual function restoration in the cognitive, motor and language areas to implement specific intervention strategies in CC.

\section{Materials and methods}

\section{Study design}

This is an observational, descriptive, longitudinal and ambispective study ${ }^{26}$ to identify the effect of age of treatment on the restoration of visual function after CC surgery and the development of a follow-up program. In all cases, the parents signed the informed consent form and the protocol was approved by the ethics and research committees of the Instituto Nacional de Pediatría with registration number 047/2015.

\section{Study population}

The study population was patients under two years of age with a diagnosis of BCC that underwent phacoemulsification from the Anterior Segment Department of the Fundación Hospital Nuestra Señora de la Luz, IAP, during the period from October 2012 to September 2014. Children who did not attend the developmental evaluation before surgery and those in whom the specialist determined concurrent ophthalmological conditions that may affect follow-up were excluded. Two children that presented post-surgical complications associated with a significant visual decrease or that were diagnosed with systemic alterations that anticipate a developmental delay were excluded. The research was conducted at the Neurodevelopment Monitoring Laboratory of the Instituto Nacional de Pediatría in Mexico City.

\section{Procedure}

Teller visual acuity cards were used to measure visual acuity, retinoscopy was used for the refractive state; the Bayley-III Scale of Infant Development was used to determine cognitive, motor and language development. Refractive value was assessed in each evaluation and the necessary changes to the prescription were made. The behaviors that require visual function for their development and expression were selected from the Bayley-III scale in the clinical examination.

The visual rehabilitation program included the use of contact lenses after surgery until one year of age; in the second year, the use of eyeglasses with a prism was implemented to correct ocular deviation, and after two years, it was modified to use bifocal lenses to compensate for distant and near vision.

The intervention program consisted of strategies to favor cognitive, motor (fine/gross), language (expressive/receptive) and social personal development ${ }^{27}$. Strategies were used to favor the development of visual function involving tasks of fixation, visual tracking, oculomotor coordination, gross and fine manipulation and hand-eye/foot-eye coordination. Attendance and participation in the intervention program and the use of prescription glasses were evaluated. A preoperative evaluation was performed based on the initial conditions and it was applied every two months until 42 months of age.

\section{Data analysis}

The patients were divided in two groups according to the age at surgery: early treatment ( $<6$ months) and late treatment ( $>6$ months). In each group the median of each test to which they were subjected was calculated, and the trend was calculated by means of a non-parametric test for ordered groups, which is an extension of the Wilcoxon rank test, using a level of significance of $p<0.05$. Statistical software Stata ${ }^{\circledR}$ (StataCorp 2013, Stata Statistical Software) was used for the analysis. 
Table 1. General characteristics

\begin{tabular}{|c|c|c|c|c|c|c|c|c|c|c|}
\hline \multirow[t]{2}{*}{ Patient } & \multirow{2}{*}{$\begin{array}{c}\text { Age at } \\
\text { follow-up } \\
\text { start } \\
\text { (months) }\end{array}$} & \multirow[t]{2}{*}{$\operatorname{Sex}$} & \multirow{2}{*}{$\begin{array}{l}\text { Cataract } \\
\text { type }\end{array}$} & \multirow{2}{*}{$\begin{array}{c}\text { Age at } \\
\text { surgery in } \\
\text { OD } \\
\text { (months) }\end{array}$} & \multirow{2}{*}{$\begin{array}{c}\text { Age at } \\
\text { surgery in } \\
\text { OS } \\
\text { (months) }\end{array}$} & \multicolumn{2}{|c|}{ Ocular disorders } & \multicolumn{2}{|c|}{ Socioeconomic status } & \multirow[b]{2}{*}{$\begin{array}{l}\text { Siblings } \\
\text { Siling } \\
\frac{1}{d}\end{array}$} \\
\hline & & & & & & $\begin{array}{l}\text { Ocular } \\
\text { deviation }\end{array}$ & Nystagmus & $\begin{array}{l}\text { Monthly } \\
\text { income } \\
\text { (\# minimum } \\
\text { wage) }\end{array}$ & $\begin{array}{l}\text { Mother's } \\
\text { Education Level }\end{array}$ & \\
\hline 1 & 2.9 & $\mathrm{M}$ & Nuclear & 5.6 & 6.0 & No & No & 7.3 & Bachelor's degree & Yes \\
\hline 2 & 2.2 & $\mathrm{~F}$ & Nuclear & 4.7 & 4.9 & XT OS & No & 2.5 & High school & Yes \\
\hline 3 & 4.1 & $\mathrm{~F}$ & Nuclear & 5.8 & 6.0 & ET OD & No & 3.4 & Technical degree & Yes \\
\hline 4 & 3.6 & $\mathrm{~F}$ & Nuclear & 4.6 & 5.6 & ET OS & Yes & 4.7 & Bachelor's degree & No \\
\hline 5 & 7.5 & $\mathrm{~F}$ & Nuclear & 8.8 & 9.0 & XT OS & No & 2.5 & Secondary school & No \\
\hline 6 & 10.5 & $\mathrm{M}$ & Nuclear & 11.2 & 11.7 & ET OD & Yes & 4.2 & Technical degree & Yes \\
\hline 7 & 6.1 & $\mathrm{M}$ & Nuclear & 7.7 & 10.4 & ET OD & Yes & 1.3 & High school & No \\
\hline 8 & 5.8 & $\mathrm{H}$ & Nuclear & 7.1 & 14.1 & ET OS & Yes & 2.6 & High school & No \\
\hline
\end{tabular}

OD: Right eye, OS: Left eye, M: Male, F: Female, XT: Exotropia, ET: Esotropia

The visual acuity estimation was converted to logMAR units and the refractive error was used in spherical equivalent for its analysis.

In the qualitative analysis, according to the evaluation of the selected behaviors that promote the visual function, three typologies were identified ${ }^{28}:$ 1) good evolution (the development reached values close to normal); 2) regular evolution (development, although improved, only fluctuated near the average), and 3) poor evolution (development remained below average).

\section{Results}

We included eight cases ( 4 girls and 4 boys) with 118 evaluations (average of 14.75 evaluations per patient), with a follow-up up to 42.1 months of age. The average age at surgery in the early treatment group was 5.6 months (range 4.9-6.0 months) and in the late treatment group, it was of 11.3 months (range 9.0-14.1 months). Table 1 shows the demographic variables of the cases.

Four patients presented nystagmus from the beginning of the follow-up and seven presented ocular deviation before and after the BCC surgery.

\section{Visual function}

Figure 1 shows the evolution of visual acuity for each eye separately by groups. Visual acuity was measured during follow-up with the use of optical correction. In the early treatment group, visual acuity shows a greater gain despite the presence of strabismus, which persists after surgery. In this group, at the end of follow-up, cases were classified with mild to moderate amblyopia, while those in the late treatment group were classified with moderate to severe amblyopia.

The visual acuity gains in each eye separately showed better results in the right eye both in the early treatment and in the late treatment groups (Fig. 1); however, statistical tests showed no significant difference $(p=0.459$ and $p=0.882)$.

In both groups, the refractive error decreased progressively and consistently, with a greater decrease in the early treatment group, which started with values of around +5.00 diopters that decreased to -0.50 diopters; however, the late treatment group started with values close to +10.00 diopters that decreased to +5.00 diopters (Fig. 2). The statistical test shows a significant difference between both groups for each eye $(p<0.01$ and $p<0.01$ ).

\section{Development}

Delays were observed in all areas before surgery in all the patients. Regarding cognitive development, the early treatment group reached a development classified as average from 13 months. In contrast, the late treatment group evolved below the average, reaching values above the average at 31 months (Fig. 3). The statistical test shows results that reflect a significant difference between both groups $(p=0.012)$. 

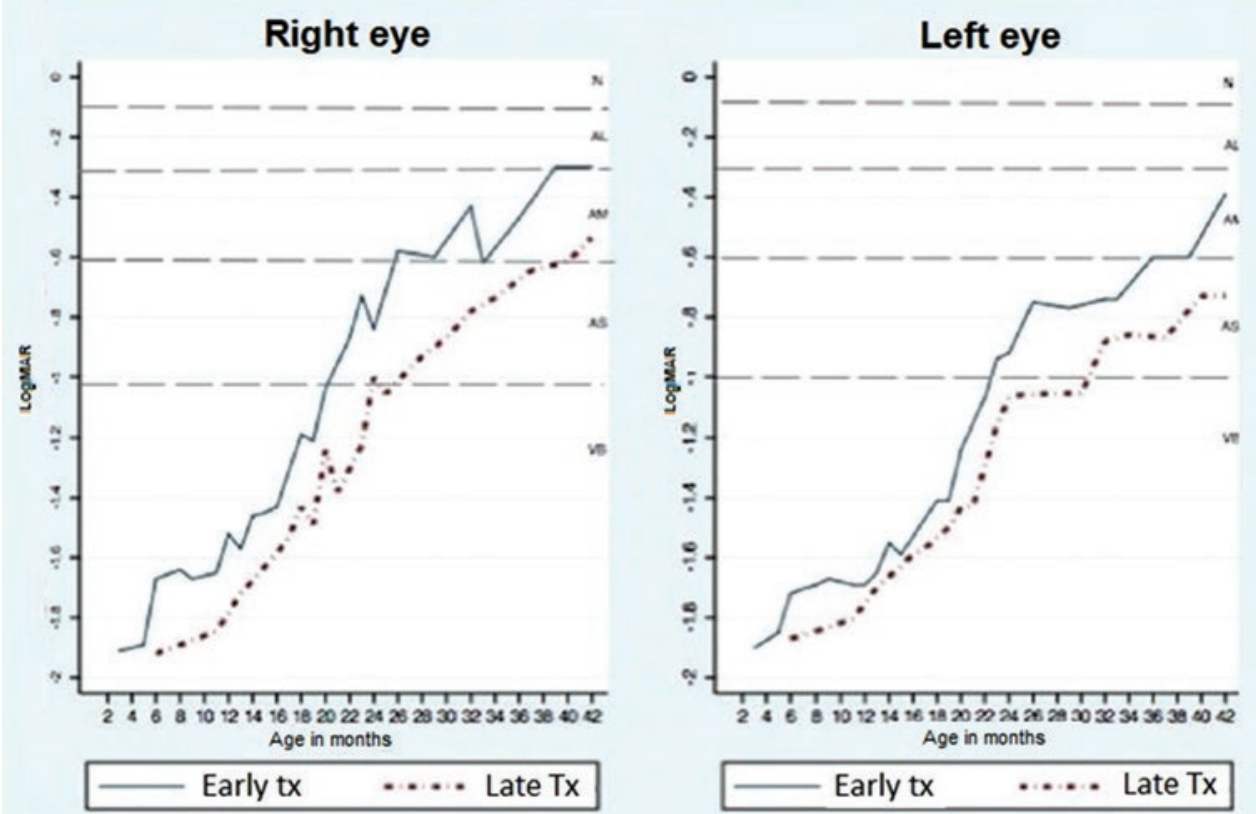

Figure 1. Postoperative visual acuity in the right eye is slightly better than in the left eye in both groups, with better performance in the early treatment group. AL: mild amblyopia; AM: moderate amblyopia; AS: severe amblyopia; $\mathrm{N}$ : normal; VB: low vision.

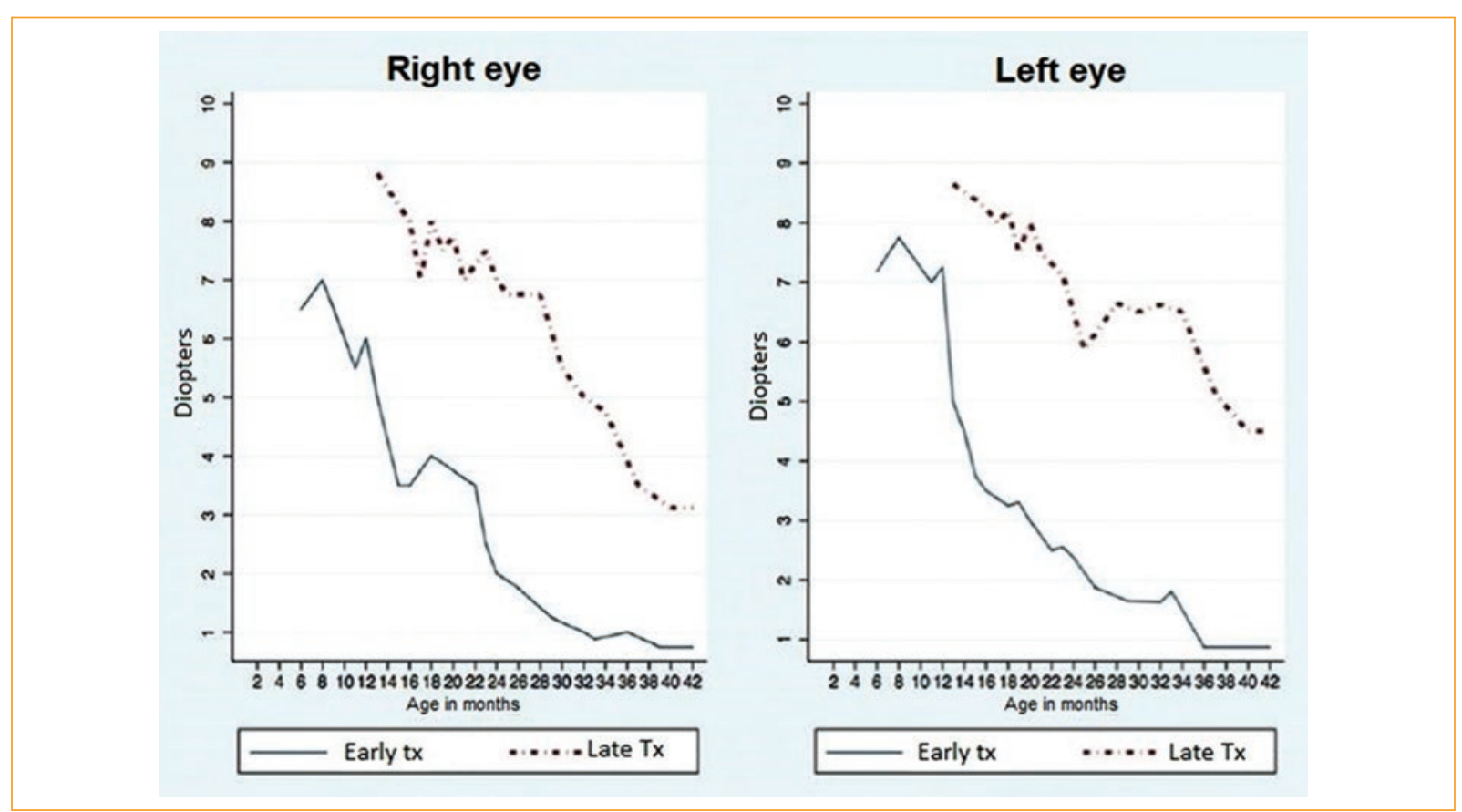

Figure 2. Refractive error using spherical equivalent is very similar in both eyes. The early treatment group shows lower onset values, maintained during follow-up. Tx: treatment.

Regarding language development, both groups evolved in a similar way. The early treatment group remained under average development until 37 months, when they reached average levels. These remained until the end of follow-up. 


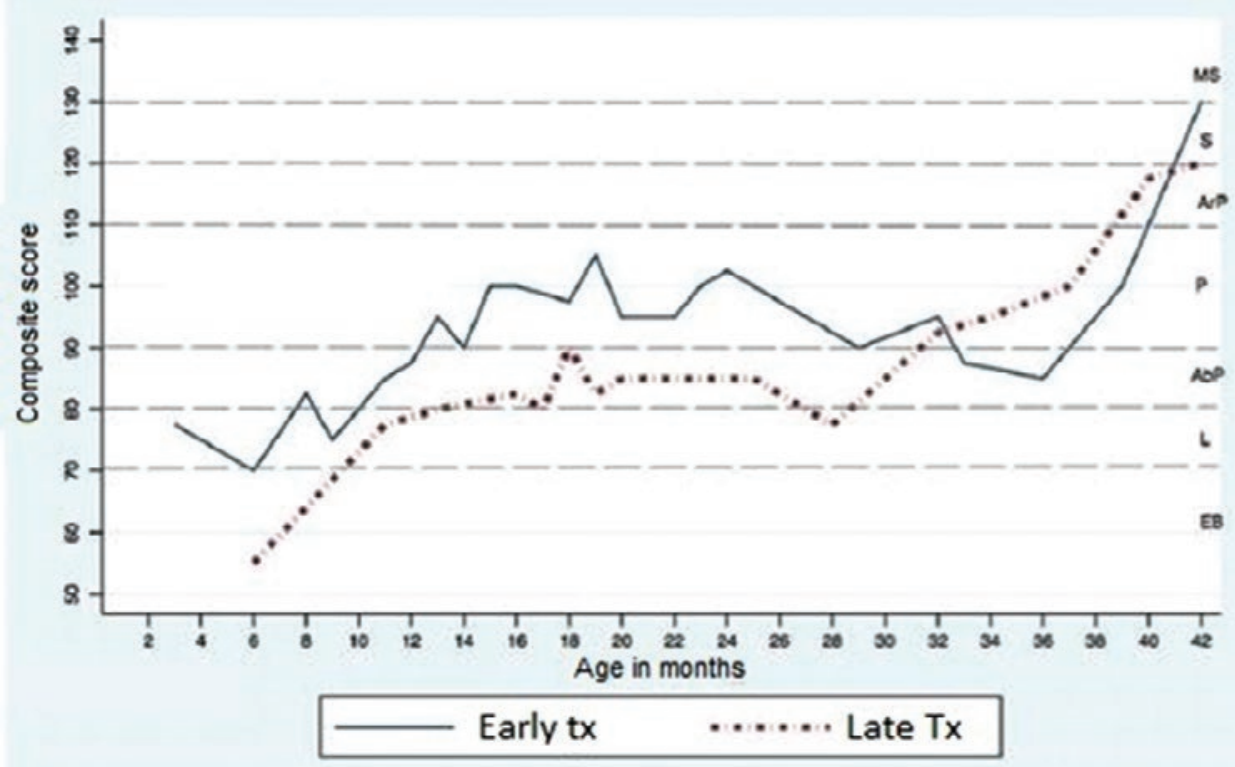

Figure 3. Bayley III Scale of Infant Development. Cognitive scale. The early treatment group starts with borderline development reaching an average value after 12 months. The late treatment group begins with an extremely low development, not reaching an average value until 31 months. AbP: below average; ArP: above average; EB: extremely low; L: borderline; MS: very superior; P: average; S: superior; Tx: treatment.

Table 2. Typology

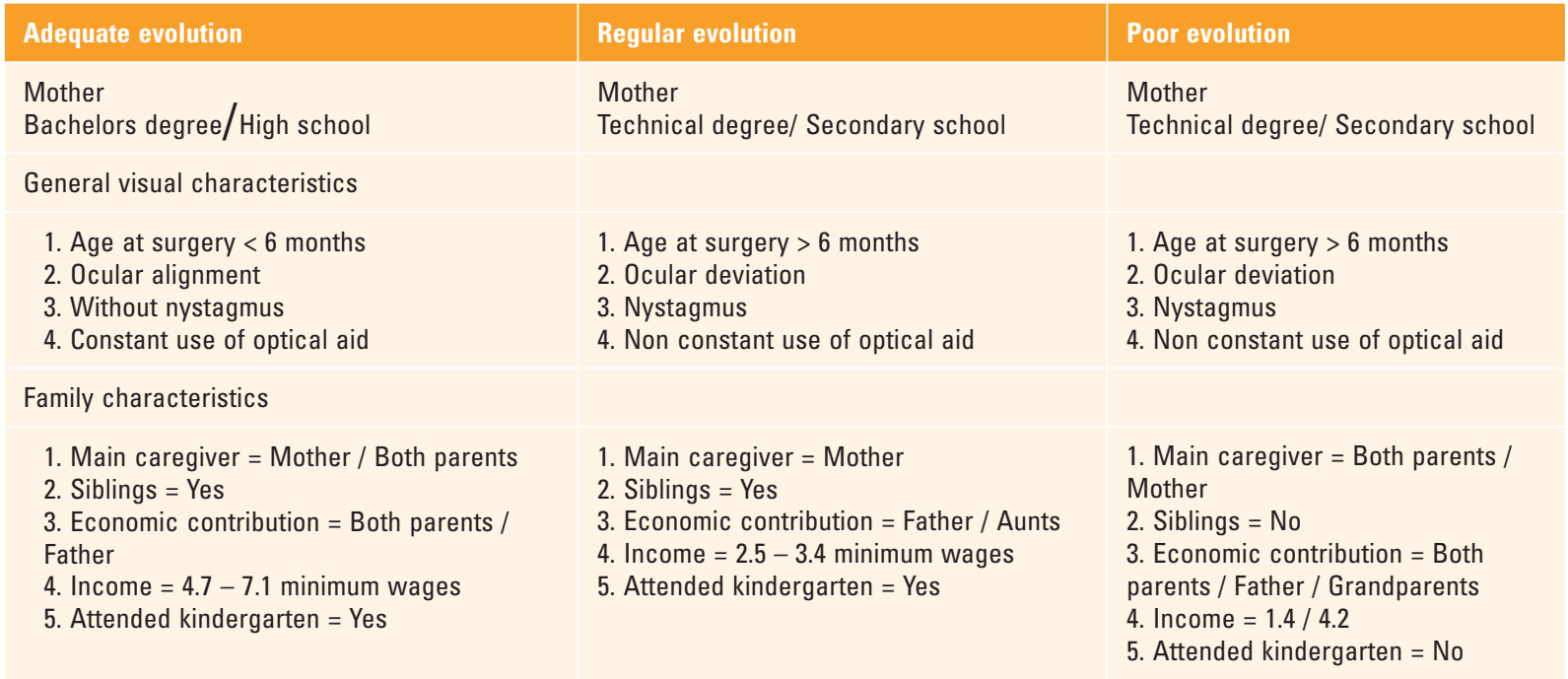

However, the late treatment group showed lower scores up to 32 months, when they reached average scores (Fig. 4). However, the statistical test does not reflect a significant difference between both groups $(p=0.677)$.

Regarding motor development, cases of early treatment showed an extremely low development from the preoperative period to 12 months after surgery, when they reached a borderline score and achieved average levels up to 18 months. The late treatment group obtained a borderline score at 4 months that improved until 22 months, when it reached an average value (Fig. 5). The statistical test shows no significant differences between both groups $(p=0.398)$.

For typologies construction, the general visual and familiar characteristics were taken into consideration (Table 2).

The visual functioning and its intervention in the clinical and behavioral expression during the follow-up 


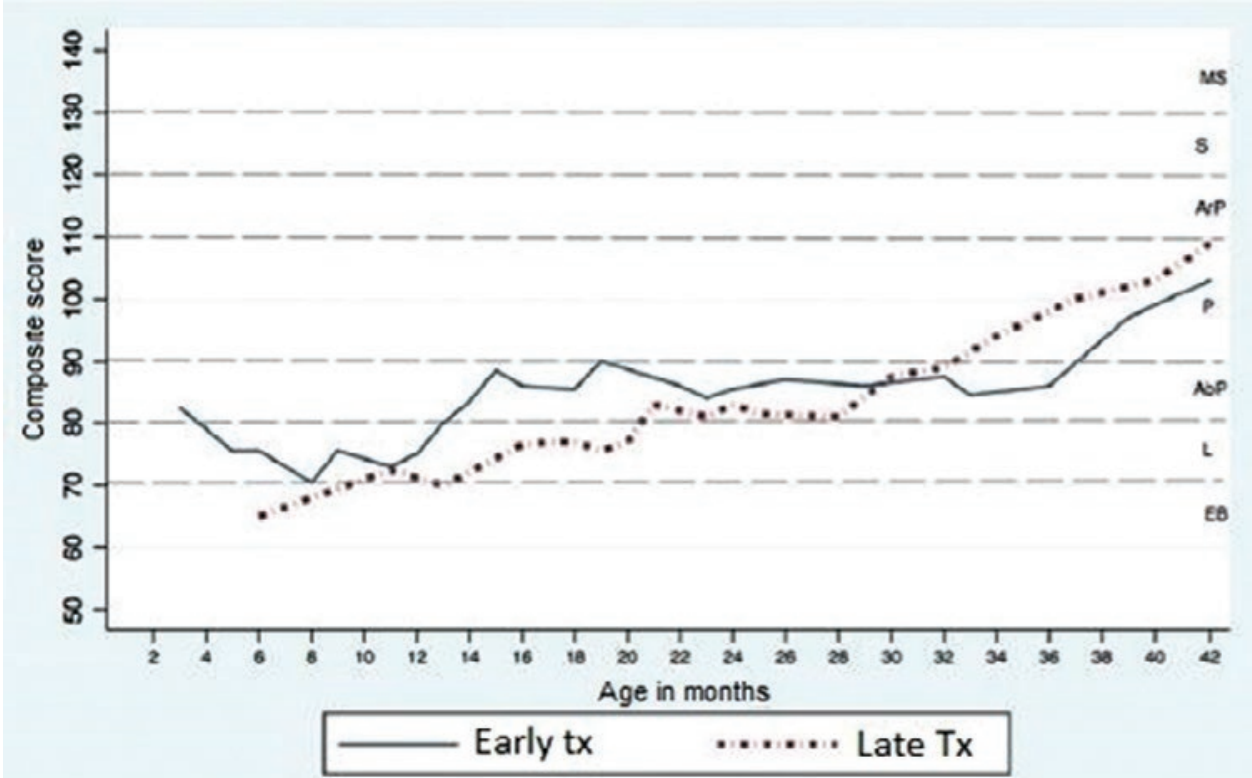

Figure 4. Bayley III Scale of Infant Development. Language scale. The early treatment group achieves an average development at 37 months, unlike the late treatment group that reaches it from 32 months. AbP: below average; ArP: above average; EB: extremely low; L: borderline; MS: very superior; P: average; S: superior; Tx: treatment.

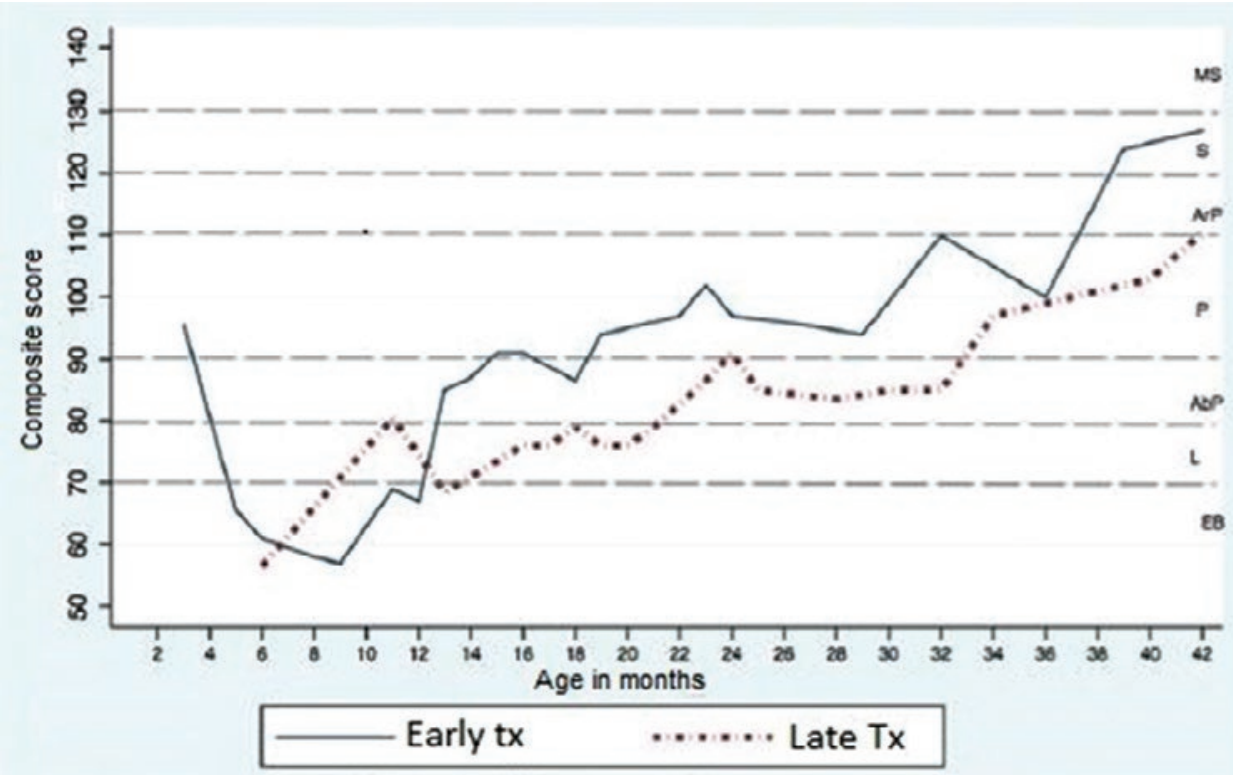

Figure 5. Bayley III Scale of Infant Development. Motor scale. The early treatment group reaches an average value from 19 months, unlike the late treatment group that achieves it until 33 months. AbP: below average; ArP: above average; EB: extremely low; L: borderline; MS: very superior; P: average; S: superior; Tx: treatment.

were described in four time-points: pre-surgical, postoperative, during the follow-up and in the last recorded evaluation (Table 3).
Considering the typology, the levels show that children with good evolution achieve expected values for age, mainly by acquiring and improving visual tasks 
Rev Mex Oftalmol (Eng). 2018;92

Table 3. Characteristics of visual functioning

\begin{tabular}{|c|c|c|c|c|c|}
\hline Typology & Preoperative & Postoperative & Follow-up & Last assessment & \\
\hline $\begin{array}{l}\text { Good Evolution } \\
\text { Acquired }\end{array}$ & 1. Response to light & $\begin{array}{l}\text { 1. Explores surroundings } \\
\text { 2. Perceives small objects } \\
\text { 3. Tracks moving objects } \\
\text { 4. Detects and takes small } \\
\text { objects with radial } \\
\text { scan-path }\end{array}$ & $\begin{array}{l}\text { 1. Precise visual fixation } \\
\text { 2. Coordinated horizontal } \\
\text { and vertical eye tracking } \\
\text { 3. Puts in and takes out } \\
\text { small objects }\end{array}$ & \multicolumn{2}{|c|}{$\begin{array}{l}\text { 1. Precise visual fixation } \\
\text { 2. Coordinated eye trackir } \\
\text { 3. Precision when } \\
\text { manipulating small } \\
\text { objects } \\
\text { 4. Identifies forms and } \\
\text { colors }\end{array}$} \\
\hline With Alteration & $\begin{array}{l}\text { 2. Weak object fixation } \\
\text { 3. Horizontal and } \\
\text { vertical eye } \\
\text { tracking is present } \\
\text { but limited with } \\
\text { fixation losses }\end{array}$ & $\begin{array}{l}\text { 5. More precise eye } \\
\text { tracking }\end{array}$ & $\begin{array}{l}\text { 4. Manipulates small } \\
\text { objects with radial } \\
\text { scan-path } \\
\text { 5. Compensatory head } \\
\text { posture }\end{array}$ & 5. Threads beads & 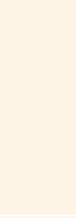 \\
\hline $\begin{array}{l}\text { Regular Evolution } \\
\text { Acquired } \\
\text { With Alteration }\end{array}$ & $\begin{array}{l}\text { 1. Response to light } \\
\text { 2. Weak object }\end{array}$ & $\begin{array}{l}\text { 1. Explores surroundings } \\
\text { 2. Perceives small objects }\end{array}$ & & & $\begin{array}{l}\frac{1}{c} \\
\frac{1}{4} \\
\frac{4}{0} \\
\frac{c}{0}\end{array}$ \\
\hline & $\begin{array}{l}\text { fixation } \\
\text { 3. Slow horizontal } \\
\text { and vertical eye } \\
\text { tracking; limited } \\
\text { with fixation losses } \\
\text { 4. Upward eye } \\
\text { movements when } \\
\text { trying to fixate }\end{array}$ & $\begin{array}{l}\text { 3. More precise eye } \\
\text { tracking } \\
\text { 4. Difficulty taking objects } \\
\text { 5. Does not track moving } \\
\text { objects }\end{array}$ & $\begin{array}{l}\text { 1. Imprecise visual fixation } \\
\text { 2. Imprecise horizontal and } \\
\text { vertical eye tracking } \\
\text { 3. Manipulates small } \\
\text { objects with radial } \\
\text { scan-path } \\
\text { 4. Imprecision when putting } \\
\text { in and taking out small } \\
\text { objects } \\
\text { 5. Compensatory head } \\
\text { posture } \\
\text { 6. Squinting when fixating }\end{array}$ & $\begin{array}{l}\text { 1. More precise vi } \\
\text { fixation } \\
\text { 2. Coordinated ey } \\
\text { tracking } \\
\text { 3. Precision when } \\
\text { manipulating sn } \\
\text { objects } \\
\text { 4. Identifies forms } \\
\text { 5. Threads beads } \\
\text { difficulty } \\
\text { 6. Difficulty to ass } \\
\text { colors with form }\end{array}$ & $\begin{array}{l}\text { jisual } \\
\text { sociate } \\
\text { ms }\end{array}$ \\
\hline $\begin{array}{l}\text { Poor Evolution } \\
\text { Acquired }\end{array}$ & 1. Response to light & $\begin{array}{l}\text { 1. Explores surroundings } \\
\text { 2. Perceives small objects }\end{array}$ & & & $\mid$ \\
\hline With Alteration & $\begin{array}{l}\text { 2. Weak object fixation } \\
\text { 3. Slow horizontal } \\
\text { and vertical eye } \\
\text { tracking; limited } \\
\text { with fixation losses } \\
\text { 4. Upward eye } \\
\text { movements when } \\
\text { trying to fixate }\end{array}$ & $\begin{array}{l}\text { 3. More precise eye } \\
\text { tracking } \\
\text { 4. Difficulty taking objects } \\
\text { 5. Does not track moving } \\
\text { objects }\end{array}$ & $\begin{array}{l}\text { 1. Imprecise visual fixation } \\
\text { 2. Imprecise horizontal and } \\
\text { vertical eye tracking } \\
\text { 3. Manipulates small } \\
\text { objects with radial } \\
\text { scan-path } \\
\text { 4. Imprecision when putting } \\
\text { in and taking out small } \\
\text { objects } \\
\text { 5. Compensatory head } \\
\text { posture } \\
\text { 6. Gets close to the } \\
\text { exploration table to } \\
\text { observe details }\end{array}$ & \multicolumn{2}{|c|}{$\begin{array}{l}\text { 1. Imprecise visual } \\
\text { fixation } \\
\text { 2. Coordinated eye } \\
\text { tracking with } \\
\text { compensatory head } \\
\text { posture } \\
\text { 3. Difficulty when } \\
\text { manipulating small } \\
\text { objects } \\
\text { 4. Difficulty to associate } \\
\text { colors with forms } \\
\text { 5. Threads beads with }\end{array}$} \\
\hline
\end{tabular}

involving fixation, precision, hand-eye and foot-eye coordination, unlike children with poor evolution who present difficulties in each area despite the age and the strategies implemented.

\section{Discussion}

CC is considered as one of the main causes of preventable visual decline and it is estimated that blindness in almost half of children could have been avoided if there was an adequate health service infrastructure, where diagnosis and early treatment represent a window of opportunity for visual function development, as well as other skills that allow optimal child development ${ }^{3,29}$.

Current evidence indicates that surgical intervention should be performed in the first weeks of life, since it is considered a period characterized by rapid changes at the level of the visual cortex ${ }^{30}$. It has been established that BCC surgery should be carried out within the first 10 weeks, since it is considered a sensitive period for visual deprivation ${ }^{31}$; however, subsequent treatment 
that includes therapeutic strategies to avoid strabismus and amblyopia is necessary ${ }^{32,33}$.

In the case of Mexico diagnosis is still late, despite the fact that the Ministry of Health emphasizes the importance of visual exploration in the first 6 months of age $^{34}$. Both the investment in the health system ${ }^{35}$ and the lack of trained personnel to perform a visual screening in the first weeks of life could affect long-term visual results, since visual loss in children considers particular strategies that are different from that of adults $^{35-37}$.

The study of CC is relevant given its high frequency and the possibility of preventing blindness with timely surgical treatment; however, research on visual postoperative evolution and cognitive development of cases is a subject that has been poorly studied. In Mexico, as in other less developed countries, there are no strategies and programs for the detection of visual anomalies or early visual rehabilitation programs for this type of disorder ${ }^{38}$.

The interest of this research lies in the analysis of developmental pathways over a prolonged period of 42 months, with several evaluated cases that did not have the opportunity to undergo surgery in the first weeks of life, whose recovery, both visual and cognitive, provides information regarding the sensitive period of functional recovery and the perspectives of late treatment, a frequent problem in developing countries.

In this study, surgical treatment was performed according to international standards, an intraocular lens was placed and there were no postoperative complications. All were included in a visual rehabilitation and intervention program, and ideal scales and statistical methods indicated in small samples were used to evaluate development. We tried to compare the results of two groups depending on the moment of the surgical intervention: early (before 6 months of age) versus late (after 6 months of age) regarding the normalized age of the tests as historical witness.

The results show that visual function is structured according to the age of treatment, since each patient has acquired each process in a different way. Visual functioning before surgery was characterized by loss of fixation, with difficulty in visually directed tasks, using proprioceptive compensations that improved once the surgery was performed. Some authors report that, as age progresses, the visual experience and its functional changes contribute not only to the function itself but also facilitates the expansion of cognitive structures. Practice allows more precise discriminations that facilitate the acquisition and permanence of structures linked to visual stimuli ${ }^{36,37}$.

The rehabilitation process used was crucial to form an adequate development. The tasks involved in promoting development in all areas based on strategies to promote visual function allowed children to acquire and improve their skills, despite the initial biological condition. Parental support and persistence in rehabilitation allowed children operated at a younger age to achieve a better performance.

The literature discusses the results of surgery according to the age of treatment; however, several studies highlight the importance of performing treatment at an early age. It is estimated that $80 \%$ of CC patients in early stages achieve a visual acuity of 20/60, contrary to patients with late treatment that achieve $20 / 200$ or worse ${ }^{39}$. Therefore, after surgery, it is essential to perform an appropriate optical correction together with visual rehabilitation and multidisciplinary follow-up to reduce complications in terms of visual results ${ }^{6}$, considering the individual, the family and their environment ${ }^{40}$. In the present study, the multidisciplinary therapeutic support of strategies to favor visual, cognitive, motor and language skills was crucial to achieve a better performance, regardless of the age at surgery, and in some children even allowed to reach normal values both in visual function and in the different areas of evaluation.

It has been reported that patients with $\mathrm{BCC}$ show a delay in hand-eye and hand-ear coordination as well as in sound localization that have a cognitive impact on the construction of object permanence. These restrictions can have cumulative impacts on postural control development, coordination and proactive mobility ${ }^{41}$, because vision is deeply integrated with the whole action system of the infant that involves posture, manual coordination, and even intelligence and personality ${ }^{42}$.

In recent decades, studies that address the impact of visual damage on child development in the areas of social adaptation, sensorimotor understanding, environmental exploration, verbal comprehension and expressive language have been published. However, there are few articles that continued researching this topic. The specialized literature on CC is abundant, but the interest is mainly focused on visual function outcomes ${ }^{43,44}$.

The delays observed during follow-up are part of the developmental process. We postulate that the reorganization of previous behaviors facing the new demands, allow more complex behaviors closely related to visual function improvement, but of slower acquisition.

The study has the limitation of including a small number of cases, although the totality of those operated in 
the hospital was investigated, whose follow-up covered a prolonged period.

The results obtained suggest that the age of treatment continues to be fundamental in visual prognosis. However, it is possible to observe that it also intervenes in global behavior, whose integrated diagnosis points to the need of establishing parallel early intervention strategies that, by involving the implementation of a systematized evaluation of visual functioning in response to standardized demands (development tests), allow timely and comprehensive intervention in children, including optical treatment in its different modalities, visual rehabilitation and early intervention of problems and motor, cognitive, linguistic and emotional disturbances, which would allow a comprehensive and adequate human development in the individual.

\section{Conclusions}

Delays in surgical treatment lead to serious alterations in visual functioning organization and leave sequelae such as the presence of strabismus, nystagmus and amblyopia. Overall development, measured by observable behaviors in the motor, cognitive and language areas, is also affected by the age at surgical intervention. It is also suggested that the duration of the sensitive period for visual function recovery seems not to be as limited and narrow as reported in the literature, where the intervention has serious influences on the final prognosis.

The age of treatment is still fundamental in visual acuity outcomes, but overall development also undergoes modifications: children operated at a higher age have a lower performance, which gradually improves thanks to the implementation of intervention strategies that favor their development.

\section{Acknowledgments}

The present study is part of the $\mathrm{PhD}$ thesis of Lizbeth Uribe Campos, Master in Neurological Rehabilitation, belonging to the Doctorate program in Biological and Health Sciences of the Universidad Autónoma Metropolitana, Xochimilco Unit.

\section{Ethical disclosures}

Protection of human and animal subjects. The authors declare that no experiments were performed on humans or animals for this study.
Confidentiality of data. The authors declare that they have followed the protocols of their work center on the publication of patient data.

Right to privacy and informed consent. The authors have obtained the written informed consent of the patients or subjects mentioned in the article. The corresponding author is in possession of this document.

\section{Funding}

This research was carried out with financial support from Fundación Hospital Nuestra Señora de la Luz, IAP, and the Instituto Nacional de Pediatría.

\section{Conflicts of interest}

There was no conflicts of interest during this research.

\section{References}

1. World Health Organization (WHO). Visual impairment and blindness. Geneva; 2014. Available at: http://www.who.int/mediacentre/factsheets/ fs282/es/. Accessed on: November 7, 2016.

2. World Health Organization (WHO). Global Initiative for the Elimination of Avoidable Blindness. Geneva; 1998. (unpublished document WHO/ PBL/97.61). Accessed on October 26, 2016.

3. Gilbert C, Foster A. Childhood blindness in the context of VISION 2020the right to sight. Bull World Health Organ. 2001;79:227-232.

4. Ramos Gómez EA, Rodríguez Masó S, Copello Noblet M, Linares Guerra M, Reselló Leyva A, Rodríguez Cabrera N.Catarata congénita y baja visión. Habilitación visual en un grupo de pacientes. Rev Haban Cienc Méd. 2011;10:61-76.

5. Kim KH, Ahn K, Chung ES, Chung TY. Clinical outcomes of surgical techniques in congenital cataracts. Kor J Ophthalmol. 2008:22:87-91.

6. Agervi $P$, Kugelberg U, Kugelberg M, Zetterström C. Refractive and visual outcome of paediatric cataract surgery in the Ukraine. Acta Ophthalmol Scand. 2006:84:674-8

7. Gogate $P$, Gilbert C, Zin A. Severe visual Impairment and blindness in infants: Causes and opportunities for control. Middle East Afr J Ophthalmol. 2011;18:109-14.

8. Drummond BA, Tartarella MB. Cirugía da catarata infantil unilateral. Arq Bras Oftalmol. 2008;71:238-41.

9. Foster A, Gilbert C, Rahi J. Epidemiology of cataract in childhood: a global perspective. J Cataract Refract Surg. 1997; 23:601-4.

10. Sheeladevi S, Lawrenson J, Fielder A, Suttle C. Global prevalence of childhood cataract: a systematic review. Eye. 2016;1-10.

11. Pérez Pérez JF, Arroyo Yllanes ME, Murillo Murillo L. Manejo de la catarata congénita: experiencia en el Hospital General de México. Rev Mex Oftalmol. 2005;79:139-44.

12. Estadistics books (data base online). General Hospital of Mexico; 2005-2015. Updated on October 26, 2015.

13. Statistic books. Asociación para Evitar la Ceguera, I.A.P; 2005-2015. Updated on October 31, 2015.

14. Statistic books. Instituto Nacional de Pediatría; 2005-2015. Updated on November 5, 2015.

15. Statistic books. Nuestra Señora de la Luz IAP Foundation Hospital for the support provided; 2005-2015. Updated on November 7, 2015.

16. Ejzenbaum F, Salomão SR, Berezovsky A, Waiswol M, Tartarella MB, Sacai PY, et al. Amblyopia after unilateral infantile cataract extraction after six weeks of age. Arq Bras Oftalmol. 2009;72:645-9.

17. Bustos ZM, Ortega RC, De la Fuente TM, Aguilar MG, Brechtel M, Hernández T, et al. Catarata congénita. Rev Hosp M Gea Glz. 2001;4:57-60.

18. Birch EE, Shimojo S, Held R. Preferential-looking assessment of fusion and stereopsis in infants aged 1-6 months. Invest Ophthalmol Vis Sci. 1985;26:366-70.

19. Hensch TK. Critical period plasticity in local cortical circuits. Nat Rev Neurosci. 2005:6:877-88 
20. Mitchell DE, Sengpiel F. Neural mechanisms of recovery following early visual deprivation. Philos Trans R Soc B Biol Sci. 2009;364:383-98.

21. Magnusson G, Persson U. Screening for congenital cataracts: a cost-consequence analysis of eye examination at maternity wards in comparison to well-baby clinics. Acta Paediatr. 2005;94:1089-95.

22. Webber AL, Wood JM, Gole GA, Brown B. The effect of amblyopia on fine motor skills in children. Invest Ophthalmol Vis Scie. 2008:49:594-603.

23. Araujo S, Estevam S, Bestillero L, Prado S. Description of the neuropsychomotor and visual development of visually impaired children. Arq Bras Oftalmol. 2010;73:526-30.

24. Banks MS, Salapatek P. Acuity and contrast sensitivity in 1-, 2-, and 3-month-old human infants. Invest Ophthalmol Vis Sci. 1978;17:361-5.

25. Putzar L, Hötting K, Röder B. Early visual deprivation affects the development of face recognition and of audio-visual speech perception. Restor Neurol and Neurosci. 2010;28:251-7.

26. Hernández SR, Fernández-Collado $C$, Baptista LP. Concepcion o elección del diseño de investigación. En: Metodología de la Investigación. $4^{\text {th }}$ ed México; 2006:157-234.

27. Sanchéz PC, Mandujano VM, Rivera GR, et al. El desarrollo integral de niño en el ciclo de vida y su cuidado. Ciencias Clínicas. 2008;2:43-51.

28. Taylor SJ, Bogdan R. Introduction to qualitative research methods. (Introducción a los métodos cualitativos de investigación). $2^{\text {nd }}$ ed. Argentina: Paidos; 1987.

29. Gogate $P$, Kalua K, Courtright P. Blindness in Childhood in Developing Countries: Time for a Reassessment?. PLoS Med. 2009;6(12):e1000177.

30. Katsumi O, Chedid SG, Kronheim JK, Henry RK, Jones CM, Hirose T. Visual Ability Score A new method to analyze ability in visually impaired children. Acta Ophthalmol. Scand. 1998;76:50-55.

31. Lloyd IC, Ashworth J, Biswas S, Abadi RV. Advances in the management of congenital and infantile cataract. Eye. 2007;21:1301-9.

32. Yorston D. Surgery for congenital cataract. Community Eye Health. 2004 17:23-5.
33. Chan WH, Biswas S, Ashworth JL, Lloyd IC. Congenital and infantile cataract: aetiology and management. Eur J Pediatr. 2012;171:625-30.

34. Instituto Méxicano de la Segurida Social (IMSS). Guía Práctica Clínica, Tratamiento Quirurgico de Catarata Congénita. Available at: http://www. imss.gob.mx/sites/all/statics/guiasclinicas/620GRR.pdf. Accessed on October 7, 2016

35. Nigenda G. El Seguro Popular de Salud en México: Desarrollo y retos para el futuro. En: Nota Técnica de Salud No. 2/2005.

36. Gardon GH, Gimenes GV, Pinheiro LM. A method to evaluate visual ability in infants. Arq Neuropsiquiatr. 2004:62:300-6.

37. Moss HA, Robson KS. The relation between the amount of time infants spend at various states and the development of visual behavior. Child Development. 1970;41:509-17.

38. Juárez-Muñoz IE, Rodríguez-Godoy ME, Guadarrama-Sotelo ME, Guerrero Anaya M, Mejía-Arangúre JM, Sciandra-Rico M. Incidence of common ophthalmological disorders in preschool children in Mexico City. Salud Pública de México. 1996;38:212-6.

39. Limburg H, Silva JC, Foster A. Cataract in Latin America: findings from nine recent surveys. Rev Panam Salud Publica. 2009;25:449-55.

40. Zetterström C, Kugelberg M. Paediatric cataract surgery. Acta Ophthalmol. Scand. 2007;85:698-710.

41. Sandoval N. Seguimiento del Neurodesarrollo en niños menores de 24 meses con diagnóstico de catarata congénita bilateral: Estudio de Casos. México: Universidad Autónoma Metrópolitana; 2011.

42. Gesell A. Diagnóstico del desarrollo normal y anormal del niño. Evaluación y manejo del desarrollo neuropsicológico normal y anormal del niño pequeño y el preescolar. 3.a ed. México; 2006.

43. McConachie HR, Moore V. Early expressive language of severely visuaIly impaired children. Dev Med And Child Neurol. 1994;36:230-40.

44. Reynell J. Developmental patterns of visually handicapped children. Child Care Health Dev. 1978;4:291-303. 